\title{
ANALISIS IMPLEMENTASI ETIKA BISNIS ISLAM PADA USAHA JUAL BELI MOBIL BEKAS DI PT BERLIAN ABADUA SATU
}

\author{
Ahadin Sadri \\ Institut ilmu Sosial dan Manajemen Stiami \\ E-mail: ahadinsadri2015@gmail.com
}

\section{ARTICLE INFO}

Keywords:

Profitability,

Customer satisfaction,

Employee engagement,

Business sustainability,

Community involvement,

Islamic business ethics

\section{ABSTRACT}

The purpose of this study is to examine the extent to which Islamic business ethics variable affect Profitability, Customer satisfaction, Employee involvement, Business continuity, and Community involvement that has been implemented at PT Berlian Abadua One, Jakarta. This research approach is quantitative with survey method The study population is all of the stakeholder elements of the company, i.e owners of companies, consumers, employees, suppliers, government, and society. The sample was 100 respondents, and the sampling technique was incidental sampling. Data analysis technique is causal analysis by using Partial Least Squares (PLS)-Structural Equation Modeling (SEM), with the help of SmartPLS 3.0 software. The results show that Islamic business ethics influences the five dependent variables. Toward Profitability, the influence of Islamic business ethics is positive and significant; while for Customer satisfaction, Employee engagement, Business continuity, and Community involvement, the influence of Islamic business ethics are positive, but not significant. This study proves that Islamic business ethics is an independent variable that has predictive power, because the value of $Q$ squares for five research models is greater than 0 (zero).

\section{PENDAHULUAN}

PT. Berlian Abadua Satu adalah anak perusahaan PT Krama Yudha Tiga Berlian Motors yang berdiri sejak tahun 1999. Perusahaan ini bergerak dalam bidang usaha sektor riil, yaitu jual beli mobil bekas, penyewaan mobil, dan bengkel umum. Khusus mengenai divisi jual beli mobil bekas dengan merek dagang "BENDI21" menunjukkan prestasi usaha yang baik. Secara rata-rata untuk periode empat tahun antara 2014 sampai dengan tahun 2017 BENDI21 mengalami pertumbuhan yang cukup signifikan, yaitu sebesar 25\%. Adapun laba kotor penjualan mobil bekas rata-rata per tahun sebesar 20\%. Sementara jumlah kontribusi profitabilitas penjualan mobil bekas terhadap total laba kotor perusahaan adalah sebesar $30 \%$. (data internal PT Berlian Abadua Satu, 2016) 
Dalam mempertahankan keberlanjutan hasil usaha yang sudah baik selama empat tahun berturut-turut tersebut, PT Berlian Abadua Satu merasakan perlunya mengetahui faktor-faktor yang berkontribusi terhadap prestasi usaha agar bisa dijadikan perhatian dari waktu ke waktu. Oleh karena itu PT Berlian Abadua Satu tahun 2017 melakuan survei terhadap responden yang berasal dari keenam pemangku kepentingan (stakeholders), yakni pemilik saham, pegawai, pelanggan, pemasok, masyarakat, dan pemerintah. Berdasarkan hasil survei konsumen tersebut dan dengan studi pada riset terdahulu, diketahui terdapat empat faktor paling kuat yang mempengaruhi tingkat keuntungan (profitability) perusahaan, yakni kepuasan pelanggan (customer satisfaction), keterlibatan karyawan (employee engagement), keberlanjutan bisnis (business continuity), dan dukungan masyarakat (community involvement).

Kepuasan pelanggan (Customer satisfaction) sejauh ini diimplementasikan BENDI21 dengan menyediakan stok mobil bekas yang berkualitas, dan memberikan jaminan servis gratis selama satu tahun yang didukung oleh staf-staf profesional. Untuk dapat menjual barang yang berkualitas, perusahaan menyeleksi sumber stok barang dagangan yang dibeli langsung dari pedagang mobil bekas perorangan maupun dari beberapa perusahaan, kemudian ditambah lagi mobil bekas dari aset perusahaan yang telah habis masa sewa kendaraan baru. Kepuasan pelanggan terhadap jual beli mobil bekas tersebut terbukti dengan cukup banyaknya pelanggan yang melakukan repeat order.

Keterlibatan sumber daya manusia atau karyawan (Employee engagement) dalam usaha jual beli mobil bekas sangatlah menentukan. Dalam hal ini PT Berlian Abadua Satu menetapkan struktur organisasi dan jobdescription yang jelas dan pasti bagi semua karyawan. Misalnya, tugas pimpinan cabang dalam hal merencanakan target dan mengawasi para karyawan menjadi semakin jelas. Setiap karyawan memiliki standar kerja masing-masing, seperti tugas sales counter yang harus menggunakan tutur kata yang bersahabat dalam memberikan informasi atau penjelasan kepada para pelanggan. Informasi mengenai kondisi stok mobil bekas kepada para pelanggan harus jelas dan transfaran, disamping itu juga informasi mengenai keunggulan dan jaminan perusahaan seperti bonus service gratis selama satu tahun, sehingga pelanggan semakin percaya dan tertarik untuk membeli mobil bekas di BENDI21.

Keberlanjutan usaha (Business continuity) sangat ditentukan oleh peranan bagian pemasaran agar produk perusahaan lebih dikenal oleh masyarakat, misalnya sarana promosi dengan melalui media internet, televisi dan media cetak. Media internet yang cukup dikenal oleh msyarakat untuk jual beli mobil bekas dapat melalui olx.com, mobil123.com, carmudi, dan yang lainnya.

Dukungan masyarakat (Community involvement) dalam tumbuh dan berkembangnya usaha jual beli mobil bekas mempunyai pengaruh yang cukup penting. Contohnya apabila tempat, lokasi dan lingkungan perusahaan tidak mendukung, maka akan menganggu operasional perusahaan. Sejauh ini perusahaan menjalin hubungan baik dengan masyarakat dengan terus meningkatkan tanggung jawab sosial perusahaan. Hubungan baik juga dijaga dengan pemangku kepentingan lain, tak terkecuali dengan aparat pemerintah mulai dari tingkat Rukun Warga, kepolis ian, Kamtibmas, hingga kantor kecamatan. 
Sejumlah penelitian telah menggunakan maqasid-syar'i (hukum atau ketentuan perundang-undangan) sebagai kerangka analisis. Penelitian Antonio et al. (2012) yang dilakukan untuk menilai kinerja perbankan di dua negera (Jordania dan Indonesia) menggunakan pendekatan Maqasid Index dengan metode Simple Additivie The Wiegtihing ( $S A W$ ). Metode tersebut digunakan peneliti untuk mengevaluasi kinerja perbankan, sebagai alternatif dari metode konvensional seperti Capital, Assdet, Management, Earning, Liquidity, Sensitivity of Market Risk (CAMELS) dan Economic Value Added (EVA). Demikian juga penelitian Hurayra (2015) pada perbankan di Bangladesh yang menggunakan kerangka pemikiran maqashid-as-syar'iyyah. Penelitian Bedoui (2015) menghasilkan kerangka pemikiran Islami berupa metrik multidimensional untuk mengukur kinerja sosial dan keuangan berkelanjutan. Laporan Ali dan Hasan (2014) juga mengajukan kerangka pemikiran untuk mengevaluasi kinerja bisnis secara Islami, yakni maqashid-as-syar'iyyah development index.

Tedapat sejumlah penelitian yang menggunakan etika bisnis Islam (Islamic business ethics/IBE) atau etika kerja Islam (Islamic work ethics/(IWE). Penelitian Marri et al. (2012) menghubungkan IWE dengan kepuasan kerja (job satisfaction) dan komitmen organisasi (organizational commitment) pada industri sektor pertanian di Pakistan. Hasil penelitian menunjukkan bahwa IWE berhubungan positif dengan kepuasan kerja maupun dengan komitmen organisasi. Penelitian senada dilakukan oleh Rokhman (2010) terhadap lembaga keuangan mikro di Demak, Jawa Tengah, Indonesia. Hasil penelitian menunjukkan terdapat hubungan positif IWE dengan kepuasan kerja dan komitmen organisasi, dan tidak ada hubungan signifikan antara IWE dengan turnover intention. Penelitian Hadisi (2014) mengenai dampak IWE terhadap kinerja pegawai muslim pada sektor pemasaran perusahaan multinasional di Iran. Hasil penelitian memperlihatkan bahwa pengaruh IWE terbukti dalam sisi moral. Misalnya, hasil kerja lebih efektif, dan konflik antar-pegawai menjadi bekurang.

Dari berbagai penelitian terdahulu terdapat persamaan dalam hal penggunaan paradima maqasid-assyar'iyyah, baik IWE maupun IBE. Perbedaannya dengan penelitian ini adalah dalam hal kelima variabel eksogen yang digunakan, objek penelitian, waktu, dan teknik analisis data penelitian. Oleh karena itu konstruk penelitian ini memiliki orisinalitas dan nilai tambah bagi penelitian-penelitian sebelumnya.

Dengan melihat variabel-variabel yang menjadi kunci keberhasilan BENDI 21 sebagai merk usaha jual-beli bekas dari PT Berlian Abadua Satu, penelitian ini bertujuan menguji apakah etika bisnis Islam (Islamic business ethics) berpengaruh terhadap kelima variabel dependen (Profitability, Customer satisfaction, Employee engagement, Business continuity, dan Community involvemen) dalam konteks bisnis syariah. Hal ini menarik diteliti, karena meskipun PT Berlian Abadua Satu tidak secara formal dan eksplisit menyatakan sebagai perusahaan yang menerapkan syariah, namun dengan observasi sementara yang dilakukan peneliti, sudah tampak bahwa sejumlah nilai-nilai bisnis perusahaan tampak terdapat kesamaan dengan nilai-nilai dalam bisnis secara syariah. 
Dengan latar belakang yang dipaparkan di atas, peneliti hendak menguji pengaruh Islamic business ethics terhadap variabel Profitability dan keempat variabel yang menjadi kunci sukses PT Berlian Abadua Satu (Customer satisfaction, Employee engagement, Business continuity, dan Community involvement).

\section{MATERI DAN METODE}

\subsection{Kajian Teoritis}

\section{Maqashid As-Syariyyah}

Jejak konsep kemaslahatan manusia atau Maqasid al-Syar'iyyiah telah disosialisasikan sejak zaman khulafur-rosyidin (empat khalifah setelah Nabi Muhammad SAW wafat), khususnya masa khalifah kedua, Umar bin al-Khattab (644 Masehi) dan pendidikan hukum pada Sekolah Maliki. Konsep Maqasid alSyar'iyyiah menekankan pada maslahah atau kepentingan publik. Pada abad ke-12, ulama Abu Hamid alGhazali (1111 Masehi) mengembangkan konsep Maqasid al-Syar'iyyiah dengan konsep lima aspek fundamental dalam kehidupan manusia, yakni: pemeliharaan agama (hifz dhin), perlindungan jiwa (hifz nafs), perlidungan keturunan (hifz nasl), pemeliharaan harta (hifz mal), dan pemeliharaan akal (hifz aql) (Jamaa, 2011). Abu Hamid al-Ghazali juga menggagas klasifikasi Maqashid-al-Syari'ah ke dalam tiga kategori, yakni: Dharuriyyah (necessities), Hajiyyah (complementary), dan Tahsiniyyah (embelishment) (Esen, 2015).

Azhari \& Chik (2011) mengklasifikasikan maqasid atas tiga macam, yakni: (i) Maqasid umum, yakni berupa tujuan yang dipertimbangkan oleh syara' dalam menentukan semua atau sebagian dari syara, misalnya konsep keadilan dan kesetaraan (al-Musawah) yang dapat ditemukan pada semua hukum syara'. Maqasid umum meliputi lima hal yang penting yang merupakan tujuan utama syariat yang membawa manfaat bagi manusia di dunia ini dan akhirat, seperti memelihara agama, jiwa, pikiran, keturunan, kekayaan, dan kehormatan. (ii) Maqasid yang spesifik, yakni maqasid yang dipertimbangkan syariah dalam menentukan sesuatu atau kelompok hukum tertentu seperti hukum keluarga, seperti sesuatu yang tidak membayahakan bagi wanita, elemen pencegahan dalam sanksi, bagaimana mencegah terjadinya penipuan dalam pengelolaan kekayaan, dan lain-lain. Maqasid spesifik ini menjadi topik diskusi para ahli fiqh. (iii) Maqasaid Juz'i, adalah maqasid yang dipertimbangkan oleh syariah dalam menentukan hukum tertentu seperti mencegah terjadinya kesulitan dalam membolehkan seseorang berbuka puasa; perwujudan perusahaan asuransi dalam larangan untuk menjaga daging dari hewan kurban.

Al-Al-Qaradawi (Azhari \& Chik, 2011) mengklasifikan maqasid dalam ilmu fiqh atas lima macam, yakni: (i) Memprioritaskan kenyamanan (taysir), (ii) Menegakkan keadilan, keadilan merupakan nilai dasar manusia dan tujuan keseluruhan kitab-kitab suci yang dikirimkan dari "langit". Keadilan yang dimaksud Qaradawi adalah keadilan dalam hukum, keadilan dalam masyarakat, dan keadilan dalam politik internasional. (iii) Ta'abud. Islam menjaga keseimbangan antara jiwa dan fisik, kesimbangan dunia dan akhirat. Menyembah Allah adalah alasan utama Allah menciptakan manusia dan alam semesta. Manusia 
tidak diciptakan untuk ekonomi, sebaliknya ekonomi diciptakan untuk manusia, dan manusia diciptakan oleh Allah untuk pergi menuju Allah.

(iv) Dakwah. Penting untuk menghubungkan fatwa-fatwa pada efek dakwah menuju Allah. Dakwah secara langsung berkaitan dengan kebiasaan universal berdasarkan yang ditemukan dalam kitab suci dan nilai-nilai kemanusiaan secara umum seperti nilai-nilai seperti kebebasan, persaudaraan, persamaan, keadilan, dan toleransi. (v) Mengobservasi fitrah. Islam adalah agama yang setara dengan fitrah manusia. Islam adalah agama yang sangat menghormati kepemilikan individu karena merupakan agama yang menghormati fitrah, menghormati kebebasan dan kemanusiaan.

Dalam pandangan Al-Syatibi, pengertian al-maslahah dalam konteks syar'i adalah mengambil manfaat dan menolak mafsadat. Manfaat ini tidak hanya bersandarkan pada pikiran dan akal sehat manusia, melainkan juga dalam rangka memelihara hak hamba Allah. Dengan kata lain, Al-Syatibi tidak menyetujui apabila akal dijadikan dasar untuk menentukan baik dan jahatnya sesuatu. Menurut Al-Syatibi, akal tidak boleh menjadi subyek atas syar'i (Mayangsari \& Noor, 2014: 53). Mengenai maslahat ini, Al-Syatibi mengemukakan dua kriteria yang harus dipenuhi, yakni: (i) Maslahat tersebut haruslah mutlak, yang berarti sifatnya bukan relatif atau subyektif. Sebab kalau bersifat subyektif dan relatif, maslahat bisa tunduk pada hawa nafsu/ (ii) Maslahat itu harus bersifat universal (kulliyah) dari universalitas ini tidak bertentangan dengan sebagian juziyat-nya (Mayangsari \& Noor, 2014).

\section{Islamic Business Ethics}

Dalam konteks bahasa, etika (ethics) berarti sifat atau karakter, perilaku dan prinsip moral dan mengatur perilaku dan nilai individu dan kelompok. Terminologi etik juga bisa bermakna sebagai sekumpulan nilai, norma, dan basis moral pada perilaku dalam kelompok sosial yang memungkinkan mereka menentukan dan membedakan kegiatan manusia itu benar atau salah, baik atau buruk. Secara umum etika merujuk pada ilmu pengetahuan yang berhubungan pada pertanyaan baik atau salah pada arena kehidupan manusia. Dari perspektif Islam, etika didefinisikan sebagai istilah yang memiliki arti sebagai al-ahlaq, yakni sifat yang tertanam dalam jiwa seseorang yang akan ditindikalanjuti dengan perbuatan tanpa membutuhkan pertimbangan pikiran sebelumnya (Mustafar \& Borhan, 2013).

Pembahasan mengenai etika bisnis dalam Islam (Islamic Business Ethics) adalah merujuk pada teori mengenai "akhlak" dalam kontek bisnis, atau lebih tepatnya disebut prinsip-prinsip akhlak. Islam merupakan sistem kehidupan yang mendasarkan pada prinsip-prinsip yang tertera dalam Al-Qur'an dan Al-Sunnah bukan pada teori-teori yang umumnya masih bersilang pendapat di antara para ahli. Pembahasan mengenai etika Islam (Islamic ethics) merupakan bagian dari kerangka akhlak (etika jiwa). Akhlak adalah istilah yang paling sering dihubungkan sebagai etika Islam.

Kerangka dasar etika bisnis dalam Islam (Islamic business ethics) terdiri dari taqwa dan ibadah kepada Allah SWT. Taqwa dan iman kepada Allah bisa diwujudkan melalui pelaksanaan ibadah wajib dan Ahadin Sadri (Analisis Implementasi Etika Bisnis Islam Pada Usaha Jual Beli Mobil Bekas... ) 
sukarela, baik berupa fardu ain (yang harus dilaksanakan oleh setiap orang) maupun fardu kifayah (yang wajib dilaksanakan oleh komunitas dan bisa gugur kewajiban bila ada satu orang saja yang melaksanakan kewajiban tersebut). Hal itu bukan hanya mengenai rukun Islam (bersyahadat, mendirikan shalat, mengeluarkan zakat, berpuasa di bulan Ramadhan, dan berhaji ke baitullah bagi orang yang mampu), namun juga menekankan pentingnya konsep halalan thoyyiba, kebersihan, pengelolaan lingkungan, serta membangun persaudaraan Islam.

Nilai-nilai utama dalam etika bisnis Islam adalah: (i) takwa adalah kerangka kerja, (ii) ibadah kepada Allah adalah prioritas, (iii) halal sebagai prioritas utama), (iv) menggunakan sumber-sumber daya secara efisien, (vi) melaksanakan nilai moral yang tinggi, tidak terlibat dalam kegiatan yang dilarang oleh Islam sebagai riba, suap, penggelapan, perzinahan, mencuri, dan lain sebagainya, (vi) kejujuran, kepercayaan, menepati janji, ketepatan waktu, dan lain-lain, (vii) perhatian untuk kesejahteraan, menolong satu sama lain terutama orang dengan miskin, orang yang membutuhkan, dan orang yang lapar, dan (viii) secara konstan mencari pengetahuan baru, (ix) produksi tidak membahayakan masyarakat dan lingkungan.

\subsection{Kerangka Pemikiran dan Hipotesis}

Penelitian ini bertitik tolak dari pemikiran mengenai bagaimana prinsip-prinisp kebajikan atau kemaslahatan (wellbeing) atau maqosid-al-syariah dapat diimplementasikan pada kehidupan modern. Penelitian ini hendak membuktikan hubungan antara maqosid al-syariah (undang-undang Islam) --- yang banyak dianggap statitik dan terputus dan realita modern (Deuraseh, 2012) dengan suatu bisnis modern, dalam hal ini pada PT Berlian Abadua Satu. Maqosid al-syariah dalam penelitian ini menggunakan proksi etika bisnis Islam (Islamic business ethics), sementara variabel-variabel yang akan dievaluasi dalam rangka implementasi etika bisnis Islam (Islamic business ethics) tersebut adalah variabel Profitability dan empat variabel yang berdasarkan hasl survei perusahaan telah terbukti mempengaruhi Profitability, yakni, Customer satisfaction, Employee engagement, Business continuity, dan Community involevement.

PT Berlian Abadua Satu secara formal bukan perusahaan syariah, namun diasumsikan sebagian praktek-praktek bisnisnya telah menjalakan prinsip maqosid-al-syariah, dalam hal ini menjalankan etika bisnis Islam. Oleh karena itu penelitian ini hendak menguji dan membuktikan sejauh mana etika bisnis Islam telah mempengaruhi kelima variabel kunci dalam sukses perusahaan tersebut.

Dalam penelitian ini posisi etika bisnis Islam diletakkan dalam tiga tataran, sehingga variabelvariabel tersebut dapat dilihat dari tiga sudut pandang (angle). Pertama, dari sudut pandang ideal, yakni das sollen, atau apa yang seharusnya, yakni bagaimana konsep ideal kemasalahatan. Kedua, adalah praktek atau implementasi dari kemaslahatan tersebut pada tataran empiris, dalam hal ini pada PT Berlian Abadua Satu. Ketiga adalah, pada tataran persepsi, pendapat atau opini dari responden (dalam ini pemangku kepentingan) sejauh mana kondisi ideal (das sollen) tersebut terlaksana pada tataran empiris (das sein). Dalam penelitian ini kuesioner disusun pada tataran kemaslahatan sebagai kondisi ideal (das sollen). Objek yang dinilai/ diteliti adalah kondisi empiris (das sein) dalam hal ini PT Berlian Abadua Satu. Sedangkan hasil penelitian 
merupakan tataran yang ketiga, yakni bagaimana persepsi para pemangku kepentingan mengenai sejauh mana kondisi kemaslahatan yang ideal diterapkan pada kondisi empiris pada PT Berlian Abadua Satu.

Berdasarkan kerangka pemikiran tersebut, maka kerangka penelitian ini dikonstruksikan seperti pada Gambar 1. Berdasarkan observasi sementara perusahaan secara informal telah menjalankan bisnis syariah, teori dan penelitian terdahulu, maka dikembangkan hipotesis sebagai berikut:

Hipotesis 1: Islamic business ethics berpengaruh terhadap Business community.

Hipotesis 2: Islamic business ethics berpengaruh terhadap Community involvement.

Hipotesis 3: Islamic business ethics berpengaruh terhadap Customer satisfaction

Hipotesis 4: Islamic business ethics berpengaruh terhadap Employee engagement

Hipotesis 5: Islamic business ethics berpengaruh terhadap Profitability

\subsection{Metode Penelitian}

Pendekatan penelitian adalah kuantitatif, dengan metode survei, menggunakan analisis inferensial, untuk mengevaluasi sejauh mana nilai kemaslahatan yang dijabarkan dalam Business Islamic ethics dapat terlaksana dalam proses dan realitas Profitability, Customer satisfaction, Employee engagement, Business continuity, dan Community envolvement pada binsis jual beli mobil bekas di PT Berlian Abadua Satu. Populasi seluruh pemangku kepentingan pada PT Berlian Abadua Satu, yang terdiri atas pemilik saham, pegawai, konsumen, pemasok, pemerintah, dan masyarakat.

Terkait sampel, ditentukan penetapan jumlah sampel, dan teknik pengambilan sampel. Untuk menentukan jumlah sampel, ditentukan dengan menggunakan rumus Tabachnick \& Fidell (2013), yakni $\mathrm{n} \geq$ $50+8 m$, dimana $n=$ jumlah sampel, dan $m$ adalah jumlah variabel independen. Dalam penelitian ini jumlah variabel indepnden adalah satu, yakni Islamic business ethics, sehingga menjadi $50+8(1)=58$ responden, yang ditingkatkan menjadi 100 responden. Adapun teknik sampling adalah sampel insidental, yakni siapa saja responden yang sesuai dengan kriteria populasi yang terlebih dahulu ditemui dan bersedia menjadi responden, maka dijadikan responden (Sugiyono, 2013). Proporsi jumlah responden dilakukan secara purposif, yang apabila jumlah responden dari keenam pemangku kepentingan tersebut diurutkan, maka urutannya (mulai yang terbesar) ke yang terkecil adalah konsumen 39 responden (39,0\%), masyarakat umum 13 responden (13,0\%), pegawai 30 responden (30\%), pemasok 8 responden (8\%), pemilik saham 5 responden $(5 \%)$, dan pemerintah 5 responden $(5 \%)$.

Data yang digunakan adalah data primer diperoleh melalui survei kepada responden; dan data sekunder melalui studi kepustakaan. Sementara itu teknik analisis data adalah analisis kausal menggunakan Partial Least Squares (PLS)-Structural Equation Modeling (SEM). Hasil penelitian yang telah diolah dengan PLS-SEM didahului dengan hasil evalusai pengukuran model yang meliputi uji outer model, dan uji inner model; kemudian diakhiri dengan uji hipotesis. Standar ukuran untuk evaluasi pengukuran model didasarkan pada asumsi bahwa penelitian ini merupakan penelitian eksplorasi, bukan penelitian uji teori; sehingga 
memiliki standar yang relatif rendah, misalnya untuk outer loading ditetapkan $0,5-0,7$ berbanding $\geq 0,7$ untuk penelitian uji teori (Widarjono, 2015: 278).

Uji outer model meliputi uji indicator reliability, discriminant validity, internal consistency, dan convergent validity. Uji indicator reliability merupakan uji validitas suatu indikator. Indikator dinyatakan valid apabila memiliki loading factor di atas 0,5 terhadap konstruk yang dituju. Dalam menguji discriminant validity, mengingat penelitian ini termasuk model reflektif, maka digunakan ukuran cross-loading dan Fornell-Larcker. Uji kelayakan cross-loading variabel indikator terhadap variabel laten yang dituju harus lebih besar nilainya dibandingkan terhadap variabel laten lainnya. Fornell-Larckel yang merupakan akar dari Average Variance Extracted (AVE), pada setiap variabel laten harus lebih besar daripada korelasi antarvaraibel laten. Widarjono (2015 dan Fanel (Yamin, 2011) merekomendasikan supaya AVE dijadikan kriteria untuk pengujian convergent validity. Uji internal consistency, untuk mengevaluasi konsistensi internal, menetapkan bahwa Cronbach's alpha harus $\geq 0,6$. Uji convergent validity menggunakan AVE yang harus lebih besar daripada 0,5 (Widarjono, 2015: 278).

Tahap pasca evaluasi outer model adalah uji inner model. Uji inner model terdiri atas dua uji, yakni: (i) Uji signifikasi, untuk mengetahui besarnya pengaruh variabel laten independen terhadap variabel laten dependen, melalui uji t. Disamping itu, uji inner model juga mengevaluasi signifikansi melalui koefisien analisis jalur (path coefficient); (ii) Uji koefisien determinasi $\left(\mathrm{R}^{2}\right)$, untuk mengukur seberapa besar variabel laten independen mampu menjelaskan variabel laten dependen (Widarjono, 2015: 278). Untuk memperkuat evaluasi outer model, juga akan diperhitungkan $Q$-square predicitive yang merupakan godness of fit pada PLS-SEM. $Q$ squares mengukur seberapa baik nilai observasi yang dihasilkan oleh model dan juga estimasi parameternya. Nilai $Q$ squares yang lebih besar daripada 0 (nol) menunjukkan bahwa model memiliki predictive relevance. Sebaliknya, jika nilai $Q$-squares kurang dari 0 (nol), berarti model tidak memiliki predictive relevance. Kriteria $Q$-squares identik dengan koefisien determinasi total, yang dirumuskan sebagai berikut (Ghozali, 2012):

$$
Q^{2}=1-\left(1-R_{1}^{2}\right)\left(1-R_{2}^{2}\right) \ldots\left(1-R_{p}^{2}\right)
$$

Dimana $\mathrm{R}_{1}{ }^{2}, \mathrm{R}_{2}{ }^{2} \ldots . . \mathrm{R}_{\mathrm{p}}{ }^{2}$ adalah $\mathrm{R}$ square variabel endogen dalam model.

\section{HASIL PENELITIAN}

\section{Uji Outer Model}

Uji outer model dilakukan dengan menguji empat indikator. Keempat indkator tersebut adalah convergent validity, indicator reliability, discriminant validity, dan internal consistency.

Hasil uji indicator reliability terhadap 48 indikator pada enam variabel laten, menunjukkan terdapat 15 indikator yang tidak valid sebagaimana tampak pada Tabel 2, karena nilai outer loading <0,5. Ke-15 
indikator yang tidak valid tersebut terdiri atas enam indikator untuk variabel Profitability (P11, P13, P22, P23, P31, dan P32); tiga indikator untuk variabel Customer satisfaction (CS13, CS31, dan CS33), satu indikator untuk variabel Employee engagement (EE22), dua indikator untuk variabel Business community (BC11, dan BC12), dua indikator untuk variabel Community involvement (CI21, dan CI23), serta satu indikator untuk variabel Business Islamic ethics (IBE11). Setelah indikator tidak valid $(<0,5)$ dikeluarkan, maka terdapat 33 indikator yang valid sebagaimana disajikan pada Tabel 3.

Hasil uji convergent validity tampak dari Average Variance Extracted (AVE) sebagaimana disajikan pada Tabel 4. Pada tabel tersebut tampak bahwa keenam variabel penelitian (Profitability, Customer satisfaction, Employee engagement, Business community, Community involvement, dan Islamic business ethics) mempunyai nilai AVE yang lebih besar dibandingkan dengan 0,5, sehingga layak dalam mengukur akurasi indikator.

Hasil uji discriminant validity tampak dari cross loading (Tabel 5) (Tabel 6). Berdasarkan Tabel 5 tampak cross loading antara indikator dan konstruknya. Korelasi konstruk Business community dengan indikatornya $(\mathrm{BC} 13=0,662 ; \mathrm{BC} 21=0,820 ; \mathrm{BC} 22=0,680 ; \mathrm{BC} 31=0,760 ;$ dan $\mathrm{BC} 32=0,602)$ lebih tinggi daripada korelasi dengan indikator lainnya (CI12=0,382; CI24=0,296; CI3 $=0,475 ; \quad$ CI41 $=0,471$; CI42=0,402; CS10,215; CS12=0,215; CS=0,278; CS14=0,217; CS2=0,246; CS32=0,220; EE11=0,302; EE12=0,225; $\quad$ EE21=0,314; $\quad$ EE12=0,225; $\quad$ EE21=0,314; $\quad$ EE23=0,291; $\quad$ EE24=0,253; EE23=0,291; EE24=0,253; EE3=0,332; EE4=1,192; IBEI12=-0,127; IBE13=-0,130; IBE21=-0,106; IBE22=-0,219; IBE23=-0,088; IBE31=-0,102; IBE32=-0,130; P12=0,115; P21=0,389). Hal ini berarti bahwa konstruk laten Business community mampu memprediksi indikator pada blog mereka lebih baik dibandingkan dengan indikator blog lainnya. Hal yang sama juga terjadi pada korelasi konstruk Community involvement, Customer satisfaction, Employee engagement, Islamic business ethics, dan Profitability.

Demikian pula nilai hubungan Community involvement ke Community involvement (0.740) lebih besar daripada nilai hubungan Community involvement ke Customer satisfaction (0,135), lebih besar daripada nilai hubungan Community involvement ke Employee engagement (0,388), lebih besar daripada nilai hubungan Community involvement ke Islamic business ethics $(-0,206)$, lebih besar daripada nilai hubungan Community involvement ke Profitability $(0,150)$.

Nilai hubungan Customer satisfaction ke Customer satisfaction $(0,765)$ lebih besar daripada nilai hubungan Customer satisfaction ke Employee engagement (0,312), lebih besar daripada nilai hubungan Customer satisfaction ke Islamic business ethics (-0,082), lebih besar daripada nilai hubungan Customer satisfaction ke Profitability $(0,211)$.

Nilai hubungan Employee engagement dengan Employee engagement (0,713) lebih besar daripada nilai hubungan Employee engagement dengan Islamic business ethics $(0,194)$, lebih besar daripada nilai hubungan Employee engagement dengan Profitability $(0,058)$. 
Nilai hubungan Islamic business ethics dengan Islamic business ethics $(0,731)$ lebih besar daripada nilai hubungan Islamic business ethics dengan Profitability (-0,279), lebih besar daripada nilai hubungan Islamic business ethics dengan Business community $(0,219)$, lebih besar daripada nilai hubungan Islamic business ethics dengan Community involvement (-0,206), lebih besar daripada nilai hubungan Islamic business ethics dengan Customer satisfaction (-0,082), lebih besar daripada nilai hubungan Islamic business ethics dengan lebih besar daripada nilai hubungan Islamic business ethics dengan Employee engagement $(0,104)$.

Demikian juga nilai hubungan Profitability dengan Profitability (0.846) lebih besar daripada nilai hubungan Profitability dengan Business community (0,219), lebih besar daripada nilai hubungan Profitability dengan Community involvement $(0,150)$, lebih besar daripada nilai hubungan Islamic business ethics dengan Customer satisfaction $(0,211)$, lebih besar daripada nilai hubungan Islamic business ethics dengan Employee engagement (0,058), lebih besar daripada nilai hubungan Islamic business ethics dengan Islamic business ethics $(-0,279)$.

Sementara itu hasil uji internal consistency diukur dengan indikator composite reliability (Tabel 7) dan cronbach's alpha (Tabel 8). Tabel 7 memperlihatkan bahwa keenam variabel memiliki nilai composite reliability > 0,6. Hal ini berarti kesemua variabel layak. Nilai composite reliability masing-masing adalah Business community (0,833), Community involvement (0,856), Customer satisfaction (0,875), Employee engagement (0,876), Islamic business (0,887), dan Profitability (0,832). Kemudian Tabel 7 memperlihatkan bahwa nilai Cronbach's alpha pada keenam variabelberada dalam posisi di atas angka 0,60. Masing-masing nilai Cronbach's alpha adalah Business community (0,766), Community involvement $(0,820)$, Customer satisfaction (0,845), Employee engagement (0,844), Islamic business (0,857), dan Profitability $(0,655)$.

Dari hasil uji terhadap empat indikator outer model di atas terbukti bahwa hasil pengukuran model telah memenuhi standar PLS-SEM. Hasil uji indicator reliability menunjukkan bahwa nilai outer loading > 0,5 untuk ke-33 indikator. Hasil uji convergent validity menunjukkan bahwa keenam variabel laten memiliki nilai AVE > 0,5 sehingga layak dalam mengukur indikator. Hasil uji discriminant validity menunjukkan bahwa cross loading variabel dengan indikator memiliki nilai korelasi yang lebih besar daripada nilai korelasi variabel tesebut dengan indikator lainnya. Selain itu hasil uji Fornell Larcker menujukkan bahwa nilai korelasi dari variabel dengan varuiabel yang bersangkutan lebih tinggi daripada nilai korelasi variabel tersebut dengan variabel lain. Sementara itu hasil internal consistency menunjukkan bahwa nilai composite realibility maupun nilai cronbach's alpha untuk masing-masing dari keenam variabel laten menunjukkan nilai >0,60, sehingga keenam variabel dianggap layak.

\section{Uji Inner Model}

Hasil uji inner model, yang diukur dengan koefisien determinasi $\left(\mathrm{R}^{2}\right)$, dan Predictive Relevance $\left(Q^{2}\right)$ menunjukkan bahwa model struktural yang dibangun robust (kuat) dan akurat. Koefisien diterminasi untuk 
keempat model, sebagaimana tampak pada Tabel 9, menunjukkan koefisien diterminasi pada kelima model penelitian.

Tabel 8 menunjukkan bahwa bahwa $R$ square $\left(R^{2}\right)$ untuk pengaruh Islamic business ethics, terhadap Business community adalah 0,031 (3,1\%). Berarti besarnya variabel laten dependen (Business community) dijelaskan oleh variabel laten independen (Islamic business ethics) adalah 3,1\%. Hal ini berarti pula bahwa penjelasan sebesar 96,90\% (100\%-3,1\%) dijelaskan oleh variabel lain di luar konstruk penelitian ini.

Kemudian t-statistik (t-hitung), sebagaimana tampak pada Tabel 8, adalah 1,241, sedangkan $\mathrm{t}$ kritis ditetapkan 1,96 (Haryono, 2017). Berarti pada model 1 (pengaruh Islamic business ethics terhadap Business community), $\mathrm{t}$ statistik $(1,241)<\mathrm{t}$ kritis $(1,96)$ yang bermakna tidak signifikan. Demikian pula nilai $p(p$ value) $(0,215)>0,05$, yang juga menunjukkan tidak signifikan. Hal ini dapat disimpulkan bahwa pengaruh Islamic business ethics terhadap Business community adalah positif, namun tidak signifikan.

Model 2, pengaruh Islamic business ethics terhadap Community involvement menunjukkan koefisien determinasi 0,042 (4,2\%). Berarti besarnya pengaruh variabel laten dependen (Community involement) yang dapat dijelaskan oleh variabel laten independen (Islamic business ethics) adalah 4,2\%. Hal ini berarti pula bahwa sisa penjelasan sebesar 95,80\% (100\%-4,2\%) dijelaskan oleh variabel lain di luar konstruk penelitian ini. Kemudian t-statistik (t-hitung) $(1,686)<\mathrm{t}$ kritis $(1,96)$ yang bermakna tidak signifikan. Nilai $p$ ( $p$-value) $(0,092)>0,05$, yang juga memengindikasikan tidak signifikan. Berarti pengaruh Islamic business ethics terhadap Community involvement adalah positif, meskipun tidak signifikan.

Model 3, pengaruh Islamic business ethics terhadap Customer satisfaction menunjukkan koefisien determinasi $0,007(0,7 \%)$. Hal ini bermakna, besarnya pengaruh variabel laten dependen (Customer satisfaction) yang dapat dijelaskan oleh variabel laten independen (Islamic business ethics) adalah 0,7\%. Hal ini berarti pula bahwa sisa penjelasan sebesar 99,30\% (100\%-0,7\%) dijelaskan oleh variabel lain di luar konstruk penelitian ini. Kemudian t-statistik (t-hitung) $(0,460)<\mathrm{t}$ kritis $(1,96)$ yang bermakna tidak signifikan. Nilai $p$ ( $p$-value) $(0,645)>0,05$, yang juga mengindikasikan tidak signifikan. Berarti pengaruh Islamic business ethics terhadap Customer satisfaction adalah positif, hanya tidak signifikan.

Model 4, pengaruh Islamic business ethics terhadap Employee engagement menunjukkan koefisien determinasi $0,038(3,8 \%)$. Hal ini bermakna, besarnya pengaruh variabel laten dependen (Employee engagement) yang dapat dijelaskan oleh variabel laten independen (Islamic business ethics) adalah 3,8\%. Berarti sisa penjelasan sebesar 96,20\% (100\%-3,8\%) mengenai Employee engagement dijelaskan oleh variabel lain di luar konstruk penelitian ini. Kemudian t-statistik (t-hitung) $(1,313)<\mathrm{t}$ kritis $(1,96)$ yang berarti tidak signifikan. Nilai $p$ ( $p$-value) $(0,190)>0,05$, yang juga menandakan tidak signifikan. Data statistik ini menunjukkan bahwa pengaruh Islamic business ethics terhadap Employee engagement adalah positif, tetapi tidak signifikan. 
Model 5, pengaruh Islamic business ethics terhadap Profitability menunjukkan koefisien determinasi 0,078 (7,8\%). Hal ini bermakna, besarnya pengaruh variabel laten dependen (Profitability) yang dapat dijelaskan oleh variabel laten independen (Islamic business ethics) adalah 7,8\%. Berarti sisa penjelasan sebesar 92,20\% (100\%-7,8\%) tentang Profitability dijelaskan oleh variabel lain di luar konstruk penelitian ini. Selanjutnya t-statistik (t-hitung) $(2,808)>t$ kritis $(1,96)$ yang berarti signifikan. Nilai $p$ ( $p$-value) $(0,005)$ $<0,05$, yang juga menandakan signifikan. Data statistik ini menunjukkan bahwa pengaruh Islamic business ethics terhadap Profitablityy adalah positif dan signifikan.

Selanjutnya perhitungan $Q^{2}$ predictive relevance untuk kelima model, sebagaimana diuraikan perhitungannya pada Tabel 10. Nilai $Q^{2}$ predictive relevance untuk model 1 (pengaruh Islamic business ethics terhadap Business community) adalah 0,001; untuk model 2 (pengaruh Islamic business ethics terhadap Communi-ty involvement) adalah 0,998556; untuk model 3 (pengaruh Islamic business ethics terhadap Customer satisfaction) adalah 0,00049; untuk model 4 (pengaruh Islamic business ethics terhadap Employee engagement) adalah 0,001444; dan untuk model 5 (pengaruh Islamic business ethics terhadap Profitabilty) adalah 0,993916. Pehitungan tersebut menunjukkan bahwa untuk kelima model Q square lebih besar daripada 0 (nol). Hal ini menunjukkan bahwa Islamic business ethics memiliki kekuatan memprediksi (predictive relevance).

\section{PEMBAHASAN}

Hasil penelitian menunjukkan bahwa Islamic business ethics secara parsial berpengaruh positif dan siginfikan terhadap Profitability. Sementara itu Islamic business ethics secara parsial berpengaruh poisitif, namun tidak signifikan terhadap Business community, Community involvement, Customer satisfaction, dan Employee engagement. Hal ini berarti penelitian ini mendukung kelima hipotesis yang diajukan.

Berdasarkan hasil penelitian tersebut, dapat dijelaskan praktek bisnis yang seusai dengan etika Islam sebagaimana diimplementasikan oleh PT.Berlian Abadua Satu, membuktikan bahwa hukum atau perundang-undangan Islam (maqasid al-syar'i) dapat diimplementasikan pada kehidupan modern, tak terkecuali pada kehidupan bisnis. Suksesnya usaha perusahaan tersebut sehingga dapat menghasilkan profit yang signifikan, membuktikan bahwa praktek bisnis secara syariah tidak menghalangi suatu perusahaan untuk membukukan laba. Prinsip undang-undang Islam yang bertujuan untuk mempromosikan kesejahteraan atau benefit (maslahah) untuk manusia dan mencegah haram (mafsadah) (Ahmed, 2011) tidak bertentangan dengan prinsip-prinsip bisnis yang sehat dan berkelanjutan. Bahkan, sebagaimana hasil penelitian yang juga dilakukan oleh perusahaan tersebut secara internal, pratek bisnis secara Islami justru memuaskan kesemua pemangku kepentingan, karena hak-hak mereka dipenuhi secara maksimal, kemudian perlakukan yang baik kepada pemangku kepentingan sebagai salah satu ajaran dalam bisnis yang beretika Islam, justru membuat kerja sama usaha menjadi lebih kokoh dan berkelanjutan. 
Secara teoritis hasil penelitian ini tidak bisa dibandingkan dengan penelitian pendahulu, karena belum ditemukan penelitian terdahulu yang kesemua variabelnya identik. Hanya persamaan penelitian ini dengan penelitian terdahulu adalah secara umum, yakni dalam hal paradigma nilai-nilai dalam maqasid-assyariyyah berkorelasi atau berpengaruh positif terhadap variabel-variebel lain yang baik (seperti kinerja, kepuasan karyawan); sementara terhadap variabel yang kurang baik seperti intention turnover tidak berpengaruh signifikan seperti penelitian Rokhman (2010).

\section{PENUTUP}

Dari hasil penelitian dapat disimpulkan Islamic business ethics secara parsial berpengaruh positif dan siginfikan terhadap Profitability. Sementara itu Islamic business ethics secara parsial berpengaruh poisitif, namun tidak signifikan terhadap Business community, Community involvement, Customer satisfaction, dan Employee engagement.

Untuk peneliti berikutnya, disarankan dapat melakukan penelitian lebih lanjut berdasarkan keterbatasan penelitian ini, antara lain dari segi variabel, objek penelitian yang berbeda, serta pendekatan penelitian kombinasi (mixed methods). Bagi perusahaan-perusahaan yang tidak/belum menerapkan prinsipprinsip Islamic business ethics, maka diharapkan memperhatikan terlebih dahulu pelaksanaan kriteria-kriteria prestasi bisnis secara umum kemudian memperhatikan etika-etika umum dalam berbisnis.

\section{DAFTAR PUSTAKA}

Ahmed, H. 2011. Maqasid as-syar'iyyah and Islamic financial products: A framework for assessment. ISRA International Journal of Islamic Finance, Vol. 3, Issue 1, pp. 149- 160.

Ali, A.J. 2011. Islamic ethics and marketing. In Ozlem, S \& Rice, G. (eds). Handbook of Islamic Marketing. UK.: Edward Elgar Publishing Limited.

Ali, S.S., \& Hasan, H. 2014. Towards a maqasid al-shariah based development index. Islamic Research and Training Institute, working paper 1435-18, pp. 1-24.

Antonio, M.S., Sanrego, Y.D., \& Taufiq, M. (2012). An analysis of Islamic banking performance: Maqashid Index implementation in Indonesia and Jordania. Journal of Islamic Finance, Vol. 1, No. 1, pp. 1229.

Arslan, Z. 2009. Islamic business ethics and its impact on strategic business decision making process of Muslims. MBA thesis. Simon Fraser Univesity, Retrieved frim http://summit.sfu.ca/item/770.

Az-Zahari, B.I.H., Chik, W.M.Y.W. 2011. "Maqasid Shariyyah According to Al-Qaradawi in the Book AlHalal wa al-Haram fi Al-Islami," International Joyrnal of Business and Social Science, Vol. $\quad 2$, No. 1, pp. 238-254. 
Bedoui, H.E. 2015. Multidimensional metrics for measuring social and sustainable finance performance. ACRN Oxford Journal of Finance and Risk Perspectives, Special Issue ofSocial and Sustainable Finance, Vol. 4, Issue 4, 109- 128.

Deuraseh, N. 2012. New essential values of daruriyyah (necessities) of the objecetives of Islamic law (maqasid as-syar'iyyah). Jurnal Hadhari, Vol. 4, No. 2, pp. 107-116.

Esen, M.F. 2015. A Statistical framework on identification of maqasid al-shariah variables for socioeconomic development index. Journal of Business Studies Quarterly, Vol. 7, Number 1, pp. 107124.

Ghazali, I. 2012. Aplikasi Analisis Multivariate dengan Program IBM SPSS, edisi 6, cetakan VI. Semarang: Badan Penerbit Universitas Diponegoro.

Haryono, S. 2017. Metode SEM untuk Penelitian Manajemen AMOS Lisrel PLS. Cetakan ke-1. Jakarta: Luxima Metro Media.

Hurayra, M.A. 2015. Achievement of maqashid-al-shar'i in Islamic banking: An evaluation of Islami Bank Bangladsh Limited. Global Journal of Computer Science and Technology: A Hardware \& Computation, Vol. 15, Issue 1, pp.8- 16.

Jamaa, La. 2011. "Dimensi Ilahi dan Dimensi Insani dalam Maqashid al-Syari’ah,” Jurnal Ilmu Syari'ah dan Hukum, Vol. 45, No. II, Juli-Desember, hal. 1251-1270.

Khan, A.A., \& Thaut, L. 2008. An Islamic perspective on fair trade. Retrived from http://www.islamicrelief.com/indepth/downloads/Islam_and_Fairtr4ade.pdf.

Marri, M.Y., Sadozai, A.M., Zaman, H.M.F., \& Ramay, M.I. (2012). Islamic work ethics on job satisfaction and organizatonal commitment: a study of agriculture sector of Pakistan. International Journal of Business and Behavioral Sciences, Vol. 2, No. 12, pp. 32- 45.

Mayangsari, G., Nashrullah, K.; Noor, H.H. 2014. "Konsep Maqashid Al-Syariah dalam Menentukan Hukum Islam,” Jurnal Al-Iqtishadiyah, Volume 1, Issue 1, Desember, hal. 50-69.

Mustafar, M.Z., \& Borhan, J,T. 2013. Muslim consumer behavior: emphasis on ethics from Islamic perspective. Middle-East Journal of Scientific Research, 18(9), 1301-1307.

Nasution, M.E. 2009. Islamic spirit and morale in economics. Journal of International Development and Cooperation, Vol. 15, pp. 113-24.

Rokhman, W. (2010). The effect of Islamic work ethics on work outcomes. Electronic Journal of Business Ethics and Organization Studies, Vol. 15, No. 1, pp. 21-27.

Ahadin Sadri (Analisis Implementasi Etika Bisnis Islam Pada Usaha Jual Beli Mobil Bekas... ) 
Saidi, T.A. 2009. Relationship between ethical and Islamic banking systems and its business management implications. South African Journal of Business Management, Vol. 4, pp. 23-49.

Sarkawi, Azila Ahmad; Alias Abdullah; Norimah Md Dali, dan Nurul Aida Salim. (2015). "Integrating Sustainability Indicators in Malaysia with Maqasid Al-Shariah (The Objective of Islamic Law), Proceedings of Adved $15 \quad$ International Conference on Advancee in Education and Social Sciences, 12-14 October, pp. 395-406.

Sugiyono. 2013. Metode Penelitian Kombinasi (Mixed Methods). Bandung: Alfabeta.

Widana, Gusti Ngurah Oka; Sudarso Kaderi Wiryono; Mustika Sufiati Purwanegara; $\quad$ Mohammad Toha. (2014). "Measuring Islamic Business Ethics Within Indonesia Islamic Banks," GJAT, Vol. 4, Issue 5, pp. 5-15

Widarjono, A. 2015. Analisis Multivariat Terapan dengan Program SPSS, AMOS, dan SMARTPLS. Yogyakarta: UPP STIM YKPN.

Yamin, S. (2014). Rahasia Olah Data Lisrel. Jakarta: Mitra Wacana Media 


\section{LAMPIRAN}

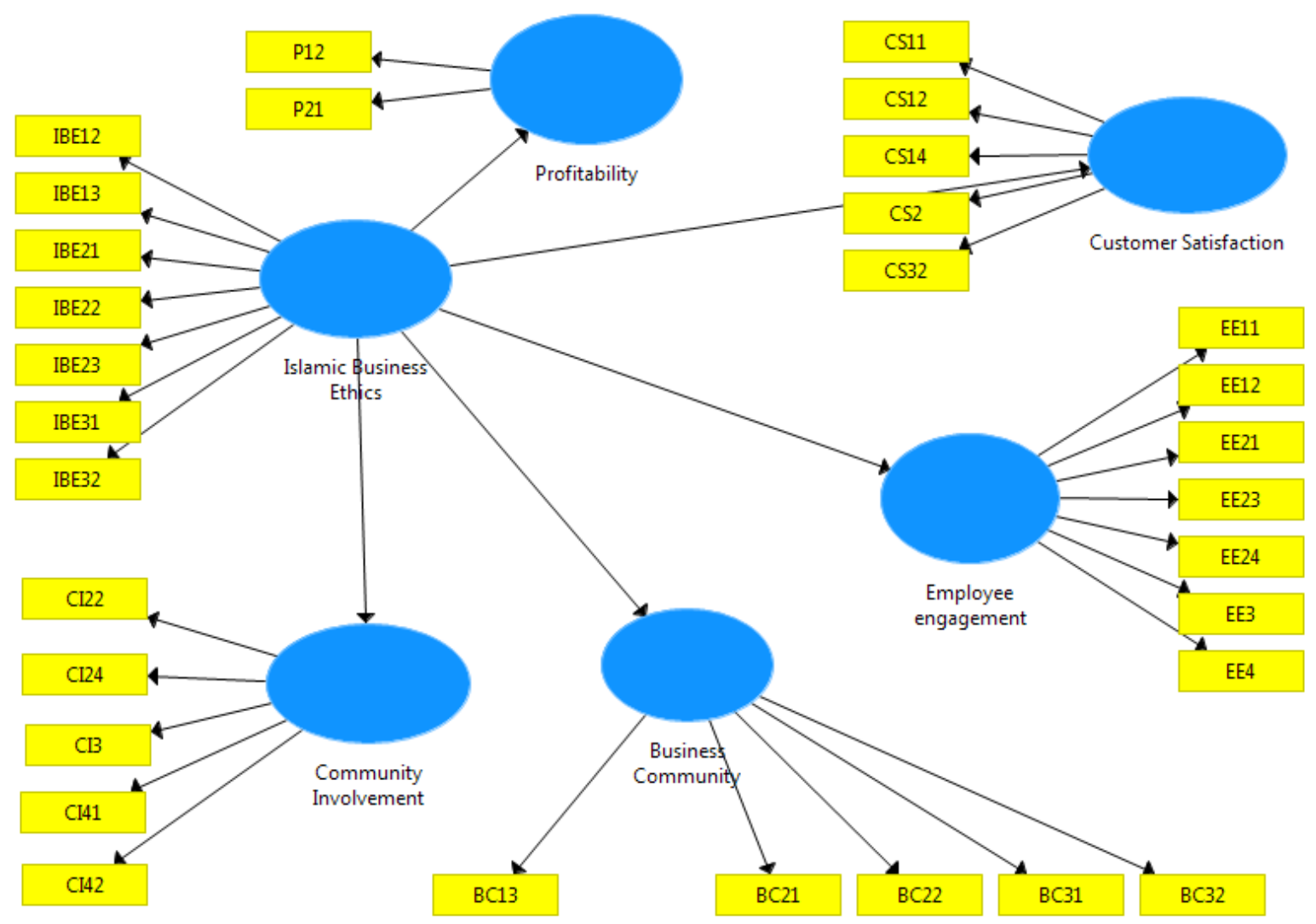

Gambar 1. Kerangka Penelitian

Tabel 1. Operasionalisasi Variabel

\begin{tabular}{|c|c|c|c|}
\hline Variabel & Dimensi & Indikator & Koding \\
\hline \multirow{8}{*}{$\begin{array}{c}\text { Islamic Business } \\
\text { Ethics }(\boldsymbol{X}) \\
\text { Saidi, 2009; } \\
\text { Nasution, 2009; } \\
\text { Ali, 2011) }\end{array}$} & \multirow[t]{3}{*}{ Tauhid } & $\begin{array}{l}\text { 1.Semua kegiatan pada dasarnya ditujukan } \\
\text { sebagai ibadah kepada Allah SWT }\end{array}$ & IBE11 \\
\hline & & $\begin{array}{l}\text { 2.Berusaha agar terjadi keberlanjutan } \\
\text { keuangan maupun sosial }\end{array}$ & IBE12 \\
\hline & & $\begin{array}{l}\text { 3.Bersikap lunak terhadap debitur yang } \\
\text { mengalami kesulitan }\end{array}$ & IBE13 \\
\hline & \multirow[t]{3}{*}{ Kebajikan } & $\begin{array}{l}\text { 4.Memperlakukan pelanggan dengan sama } \\
\text { terlepas dari perbedaan tingkat ekonomi, } \\
\text { kapasitas membeli, dan kesadaran dalam } \\
\text { pemasaran }\end{array}$ & IBE21 \\
\hline & & 5. Melarang terjadinya pemborosan & IBE22 \\
\hline & & $\begin{array}{l}\text { 6. Tidak memperbolehkan keserakahan } \\
\text { dalam mencapai status, kekayaan yang } \\
\text { lebih tinggi }\end{array}$ & IBE23 \\
\hline & \multirow[t]{2}{*}{ Keseimbangan } & 7. Proporsional dalam bertindak & IBE31 \\
\hline & & 8. Kejujuran & IBE32 \\
\hline & & $\begin{array}{l}\text { 1.Perusahaan mengambil untung (profit) } \\
\text { dalam batas yang wajar (sekitar } 10 \% \text { ) }\end{array}$ & P-1 \\
\hline
\end{tabular}




\begin{tabular}{|c|c|c|c|}
\hline \multirow{7}{*}{ Profitability $\left(\mathbf{Y}_{1}\right)$} & \multirow{2}{*}{$\begin{array}{l}\text { Profit yang } \\
\text { halal }\end{array}$} & $\begin{array}{l}\text { 2.Perusahaan tidak mengambil keuntungan } \\
\text { dari bunga/ riba }\end{array}$ & \multirow{5}{*}{ P-2 } \\
\hline & & $\begin{array}{lll}\text { 3.Perusahaan } & \text { menghindari } & \text { sifat } \\
\text { keserekahan } & & \end{array}$ & \\
\hline & \multirow{3}{*}{$\begin{array}{l}\text { Pemenuhan } \\
\text { kewajiban }\end{array}$} & $\begin{array}{l}\text { 4.Perusahaan memberikan upah yang layak } \\
\text { kepada segenap pegawainya }\end{array}$ & \\
\hline & & $\begin{array}{l}\text { 5.Perusahaan telah memenuhi } \\
\text { kewajibannya kepada pemerintah (pajak, } \\
\text { dll) }\end{array}$ & \\
\hline & & $\begin{array}{l}\text { 6.Perusahaan telah memenuhi kewajiban } \\
\text { pada pemerintah dalam hal } \\
\text { ketenagakerjaan (seperti BPJS) }\end{array}$ & \\
\hline & \multirow[t]{2}{*}{$\begin{array}{l}\text { Harga yang } \\
\text { wajar }\end{array}$} & $\begin{array}{l}\text { 7.Perusahaaan menetapkan harga penjualan } \\
\text { dengan wajar }\end{array}$ & \multirow[t]{2}{*}{ P-3 } \\
\hline & & $\begin{array}{l}\text { 8.Perusahaaan menegosiasikan harga } \\
\text { pembelian dengan wajar }\end{array}$ & \\
\hline \multirow{8}{*}{$\begin{array}{c}\text { CUSTOMER } \\
\text { SATISFACTION } \\
\left(\mathrm{Y}_{2}\right)\end{array}$} & \multirow{4}{*}{ Jujur } & $\begin{array}{l}\text { 9. Perusahaan menyampaikan semua hal } \\
\text { kepada konsumen dengan penuh kejujuran }\end{array}$ & \multirow[t]{4}{*}{ CS-1 } \\
\hline & & $\begin{array}{l}\text { 10. Perusahaan tidak menyembunyikan } \\
\text { informasi kepada konsumen (asymmetric } \\
\text { information) }\end{array}$ & \\
\hline & & $\begin{array}{l}11 . \quad \text { Perusahaan tidak melakukan } \\
\text { kecurangan }\end{array}$ & \\
\hline & & $\begin{array}{l}\text { 12. Perusahaan tidak menyembunyikan } \\
\text { barang yang cacat }\end{array}$ & \\
\hline & Garansi & $\begin{array}{l}\text { 13. Perusahaan bertanggung jawab dalam } \\
\text { melaksanakan garansi }\end{array}$ & $\mathrm{CS}-2$ \\
\hline & \multirow[t]{3}{*}{ Adil } & $\begin{array}{l}\text { 14. Perusahaan melakukan negosiasi secara } \\
\text { adil dalam pembuatan perjanjian }\end{array}$ & \multirow[t]{3}{*}{ CS-3 } \\
\hline & & $\begin{array}{l}\text { 15. Perusahaan memperlakukan konsumen } \\
\text { dengan sama/ setara }\end{array}$ & \\
\hline & & $\begin{array}{l}\text { 16. Perusahaan memberikan toleransi } \\
\text { kepada konsumen yang mengalami } \\
\text { kesulitan keuangan }\end{array}$ & \\
\hline \multirow{7}{*}{$\begin{array}{c}\text { EMPLOYEE- } \\
\text { ENGAGEMENT } \\
\left(Y_{3}\right)\end{array}$} & \multirow[t]{2}{*}{ Rendah hati } & $\begin{array}{l}\text { 17.Segenap pegawai perusahaan ini } \\
\text { menunjukkan sifat rendah hati }\end{array}$ & \multirow[t]{2}{*}{ EE-1 } \\
\hline & & $\begin{array}{l}\text { 18.Segenap pegawai perusahaan ini } \\
\text { menunjukkan sifat kesederhanaan }\end{array}$ & \\
\hline & \multirow[t]{4}{*}{$\begin{array}{l}\text { Tanggung } \\
\text { jawab }\end{array}$} & $\begin{array}{l}\text { 19. Segenap pegawai perusahaan ini } \\
\text { memiliki tanggung jawabnya masing- } \\
\text { masing }\end{array}$ & \multirow[t]{4}{*}{ EE-2 } \\
\hline & & $\begin{array}{l}\text { 20. Pegawai perusahaan ini tidak saling } \\
\text { menyalahkan satu sama lain }\end{array}$ & \\
\hline & & $\begin{array}{l}\text { 21. Pegawai dapat melakukan kontrol/ } \\
\text { pengawasan pada pekerjaannya masing- } \\
\text { masing }\end{array}$ & \\
\hline & & $\begin{array}{l}\text { 22. Pegawai bekerja sesuai dengan standar } \\
\text { operasional perusahaan (SOP) }\end{array}$ & \\
\hline & $\begin{array}{l}\text { Sense } \\
\text { belonging }\end{array}$ & $\begin{array}{l}\text { 23.Pegawai merasa ikut memiliki } \\
\text { perusahaan (sense of belonging) }\end{array}$ & EE-3 \\
\hline
\end{tabular}




\begin{tabular}{|c|c|c|c|}
\hline & Gagasan & $\begin{array}{l}\text { 24. Pegawai memberikan gagasan yang } \\
\text { baik untuk kemajuan perusahaan }\end{array}$ & EE-4 \\
\hline \multirow{8}{*}{$\begin{array}{l}\text { BUSINESS } \\
\text { CONTINUITY } \\
\left(\mathrm{Y}_{4}\right)\end{array}$} & \multirow[t]{4}{*}{ Kualitas usaha } & $\begin{array}{l}\text { 25.Perusahaan melakukan efisiensi dalam } \\
\text { segala hal }\end{array}$ & \multirow[t]{4}{*}{ BC-1 } \\
\hline & & $\begin{array}{l}\text { 26.Perusahaan bersikap proporsional dalam } \\
\text { segala tindakan }\end{array}$ & \\
\hline & & $\begin{array}{l}\text { 27.Perusahaan melakukan kegiatan usaha } \\
\text { secara sehat }\end{array}$ & \\
\hline & & $\begin{array}{l}\text { 28.Perusahaan } \\
\text { kualitas usaha }\end{array}$ & \\
\hline & \multirow[t]{2}{*}{ Keberlanjutan } & $\begin{array}{l}\text { 29.Perusahaan menjaga keberlanjutan } \\
\text { secara bisnis }\end{array}$ & \multirow[t]{2}{*}{$\mathrm{BC}-2$} \\
\hline & & $\begin{array}{l}\text { 30.Perusahaan menjaga keberlanjutan } \\
\text { secara sosial }\end{array}$ & \\
\hline & \multirow{2}{*}{$\begin{array}{l}\text { Relasi dengan } \\
\text { pemangku } \\
\text { kepentingan }\end{array}$} & $\begin{array}{l}\text { 31.Perusahaan mempertimbangkan } \\
\text { kepentingan sosial terkait dengan pemasok }\end{array}$ & \multirow[t]{2}{*}{$\mathrm{BC}-3$} \\
\hline & & $\begin{array}{l}\text { 32.Perusahaan menjalin hubungan yang } \\
\text { baik dengan pemangku kepentingan } \\
\text { (stakeholders) }\end{array}$ & \\
\hline \multirow{8}{*}{$\begin{array}{l}\text { COMMUNITY } \\
\text { INVOLEMENT } \\
\text { (Y5) }\end{array}$} & Zakat & $\begin{array}{l}\text { 33.Perusahaan mengeluarkan zakat sesuai } \\
\text { aturan syariah }\end{array}$ & CI-1 \\
\hline & \multirow[t]{5}{*}{$\begin{array}{l}\text { Kepentingan } \\
\text { sosial }\end{array}$} & $\begin{array}{l}\text { 34.Perusahaan lebih mengutamakan } \\
\text { kepentingan sosial daripada kepentingan } \\
\text { perusahaan }\end{array}$ & \multirow[t]{5}{*}{ CI-2 } \\
\hline & & $\begin{array}{l}\text { 35.Perusahaan memiliki solidaritas yang } \\
\text { tinggi terhadap masyarakat sekitarnya }\end{array}$ & \\
\hline & & $\begin{array}{l}\text { 36.Perusahaan menunjukkan sikap } \\
\text { tanggung jawab sosial yang tinggi }\end{array}$ & \\
\hline & & $\begin{array}{l}\text { 37.Perusahaan mengalokasikan dana sosial } \\
\text { (corporate social responsibility/CSR) }\end{array}$ & \\
\hline & & $\begin{array}{l}\text { 38.Perusahaan ikut ambil bagian dalam } \\
\text { melaksanakan kegiatan hari-hari besar } \\
\text { nasional }\end{array}$ & \\
\hline & $\begin{array}{l}\text { Pemangku } \\
\text { kepentingan }\end{array}$ & $\begin{array}{l}\text { 39.Perusahaan memperlakukan } \\
\text { stakeholders dengan proporsional }\end{array}$ & CI-3 \\
\hline & $\begin{array}{l}\text { Lingkungan } \\
\text { hidup }\end{array}$ & $\begin{array}{l}\text { 40.Perusahaan ikut ambil bagian dalam } \\
\text { melaksanakan kegiatan hari-hari besar } \\
\text { nasional }\end{array}$ & CI-4 \\
\hline
\end{tabular}




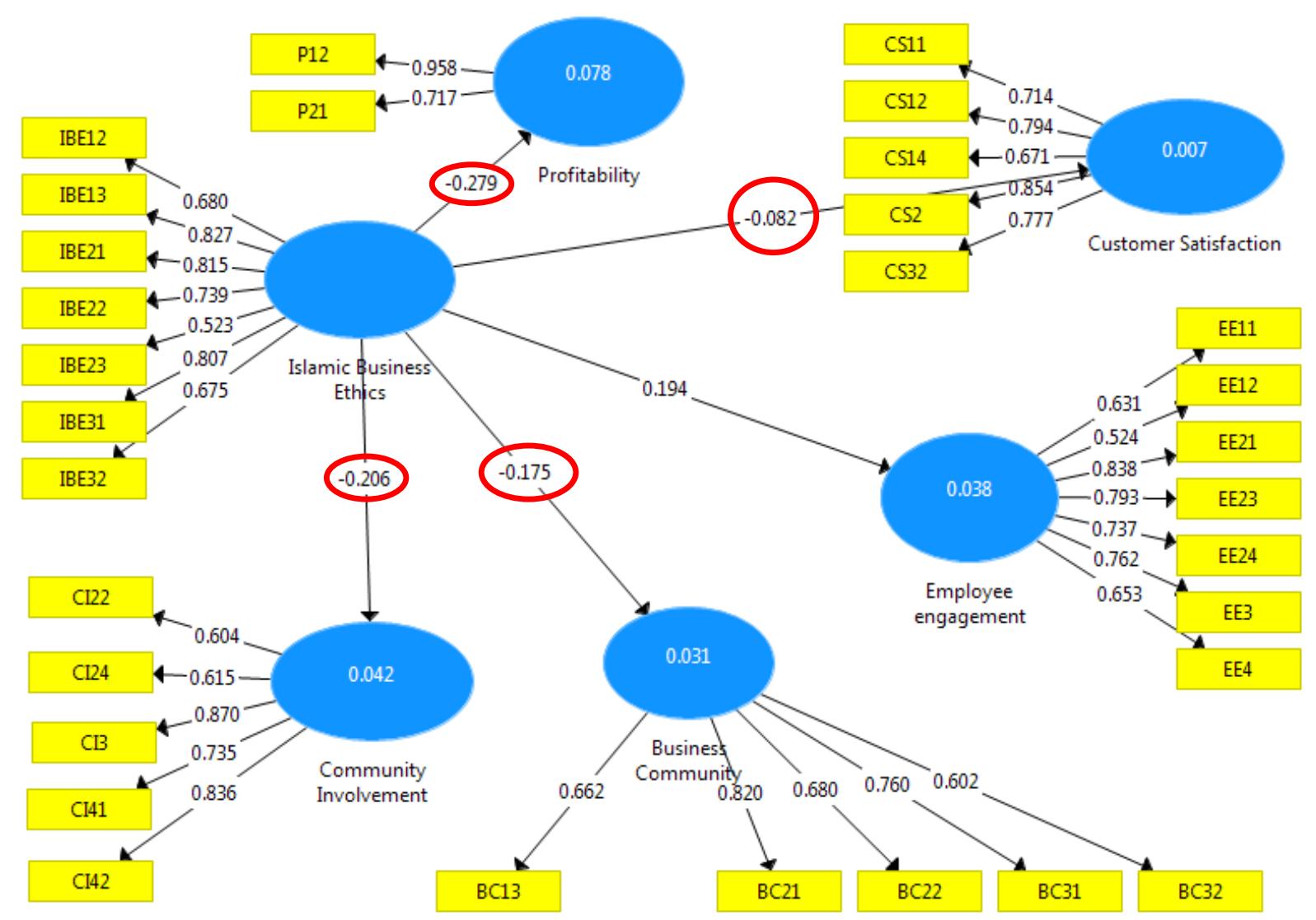

Gambar 2. Outer Loading

Tabel 2. Outer Loading pada Running Pertama

\begin{tabular}{|c|c|c|c|c|c|c|c|}
\hline Kode & $\begin{array}{c}\text { Variabel } \\
\text { Laten }\end{array}$ & $\begin{array}{l}\text { Indi- } \\
\text { kator }\end{array}$ & $\begin{array}{c}\text { Outer } \\
\text { Louding }\end{array}$ & $\begin{array}{c}\text { Ketera } \\
\text { ngan }\end{array}$ & $\begin{array}{l}\text { Indi- } \\
\text { kator }\end{array}$ & $\begin{array}{c}\text { Outer } \\
\text { Louding }\end{array}$ & $\begin{array}{c}\text { Kete- } \\
\text { rangan }\end{array}$ \\
\hline \multirow[t]{4}{*}{$\mathrm{P}$} & \multirow[t]{4}{*}{ Profitability } & P11 & $-0,442$ & $\begin{array}{l}\text { Tidak } \\
\text { valid }\end{array}$ & $\mathrm{P} 22$ & $-0,091$ & $\begin{array}{l}\text { Tidak } \\
\text { valid }\end{array}$ \\
\hline & & $\mathrm{P} 12$ & 0,784 & Valid & P23 & $-0,155$ & $\begin{array}{l}\text { Tidak } \\
\text { valid }\end{array}$ \\
\hline & & P13 & 0,340 & $\begin{array}{l}\text { Tidak } \\
\text { valid }\end{array}$ & P31 & 0,260 & $\begin{array}{l}\text { Tidak } \\
\text { valid }\end{array}$ \\
\hline & & $\mathrm{P} 21$ & 0,665 & Valid & P32 & 0,099 & $\begin{array}{l}\text { Tidak } \\
\text { valid }\end{array}$ \\
\hline \multirow[t]{4}{*}{$\mathrm{CS}$} & \multirow{4}{*}{$\begin{array}{l}\text { Customer } \\
\text { Satisfaction }\end{array}$} & CS11 & 0,683 & Valid & CS2 & 0,807 & Valid \\
\hline & & CS12 & 0,771 & Valid & CS31 & 0,460 & $\begin{array}{l}\text { Tidak } \\
\text { valid }\end{array}$ \\
\hline & & CS13 & 0,331 & $\begin{array}{l}\text { Tidak } \\
\text { valid }\end{array}$ & CS32 & 0,754 & Valid \\
\hline & & CS14 & 0,693 & Valid & CS33 & 0,354 & $\begin{array}{l}\text { Tidak } \\
\text { valid }\end{array}$ \\
\hline \multirow[t]{4}{*}{$\mathrm{EE}$} & \multirow{4}{*}{$\begin{array}{l}\text { Employee } \\
\text { Engagement }\end{array}$} & EE11 & 0,609 & Valid & EE23 & 0,790 & Valid \\
\hline & & EE12 & 0,503 & Valid & EE24 & 0,725 & Valid \\
\hline & & EE21 & 0,855 & Valid & EE3 & 0,757 & Valid \\
\hline & & EE22 & 0,449 & Tidak & EE4 & 0,662 & Valid \\
\hline
\end{tabular}




\begin{tabular}{|c|c|c|c|c|c|c|c|}
\hline Kode & $\begin{array}{c}\text { Variabel } \\
\text { Laten }\end{array}$ & $\begin{array}{l}\text { Indi- } \\
\text { kator }\end{array}$ & $\begin{array}{c}\text { Outer } \\
\text { Louding }\end{array}$ & $\begin{array}{c}\text { Ketera } \\
\text { ngan }\end{array}$ & $\begin{array}{l}\text { Indi- } \\
\text { kator }\end{array}$ & $\begin{array}{c}\text { Outer } \\
\text { Louding }\end{array}$ & $\begin{array}{c}\text { Kete- } \\
\text { rangan }\end{array}$ \\
\hline & & & & valid & & & \\
\hline \multirow[t]{4}{*}{$\mathrm{BC}$} & \multirow[t]{4}{*}{$\begin{array}{l}\text { Business } \\
\text { Communitu }\end{array}$} & BC11 & 0,173 & $\begin{array}{l}\text { Tidak } \\
\text { valid }\end{array}$ & BC21 & 0,808 & Valid \\
\hline & & BC12 & 0.440 & $\begin{array}{l}\text { Tidak } \\
\text { valid }\end{array}$ & $\mathrm{BC} 22$ & 0,690 & Valid \\
\hline & & BC13 & 0,700 & Valid & BC31 & 0,738 & Valid \\
\hline & & BC14 & 0,516 & Valid & BC32 & 0,578 & Valid \\
\hline \multirow{4}{*}{ CI } & \multirow{4}{*}{$\begin{array}{l}\text { Community } \\
\text { Involvement }\end{array}$} & CI1 & 0,329 & Valid & CI24 & 0,585 & Valid \\
\hline & & CI21 & 0,499 & $\begin{array}{l}\text { Tidak } \\
\text { valid }\end{array}$ & C13 & 0,876 & Valid \\
\hline & & CI22 & 0,593 & Valid & C141 & 0,699 & Valid \\
\hline & & C123 & 0,491 & $\begin{array}{l}\text { Tidak } \\
\text { valid }\end{array}$ & $\mathrm{C} 142$ & 0,847 & Valid \\
\hline \multirow[t]{4}{*}{ BIE } & \multirow{4}{*}{$\begin{array}{l}\text { Islamic } \\
\text { Business } \\
\text { Ethics }\end{array}$} & IBE11 & 0,325 & $\begin{array}{l}\text { Tidak } \\
\text { valid }\end{array}$ & IBE22 & 0,750 & Valid \\
\hline & & IBEI2 & 0,623 & Valid & IBE23 & 0,518 & Valid \\
\hline & & IBE13 & 0,820 & Valid & IBE31 & 0,829 & Valid \\
\hline & & IBE21 & 0,804 & Valid & IBE32 & 0,729 & Valid \\
\hline
\end{tabular}

Tabel 3. Outer Loading pada Running Kedua

\begin{tabular}{|c|c|c|c|c|c|c|c|}
\hline Kode & $\begin{array}{c}\text { Variabel } \\
\text { Laten }\end{array}$ & $\begin{array}{l}\text { Indi- } \\
\text { kator }\end{array}$ & $\begin{array}{c}\text { Outer } \\
\text { Louding }\end{array}$ & $\begin{array}{c}\text { Ketera } \\
\text { ngan }\end{array}$ & $\begin{array}{l}\text { Indi- } \\
\text { kator }\end{array}$ & $\begin{array}{c}\text { Outer } \\
\text { Louding }\end{array}$ & $\begin{array}{l}\text { Kete- } \\
\text { rangan }\end{array}$ \\
\hline & Profitability & P12 & 0,958 & Valid & $\mathrm{P} 21$ & 0,717 & Valid \\
\hline \multirow[t]{3}{*}{$\mathrm{CS}$} & \multirow{3}{*}{$\begin{array}{l}\text { Customer } \\
\text { Satisfaction }\end{array}$} & CS11 & 0,714 & Valid & $\mathrm{CS} 2$ & 0,854 & Valid \\
\hline & & CS12 & 0,794 & Valid & CS31 & 0,777 & Valid \\
\hline & & CS14 & 0,671 & Valid & & & \\
\hline \multirow[t]{4}{*}{$\mathrm{EE}$} & \multirow{4}{*}{$\begin{array}{l}\text { Employee } \\
\text { Engagement }\end{array}$} & EE11 & 0,631 & Valid & EE24 & 0,737 & Valid \\
\hline & & EE12 & 0,524 & Valid & EE3 & 0,762 & Valid \\
\hline & & EE21 & 0,838 & Valid & EE4 & 0,653 & Valid \\
\hline & & EE23 & 0,793 & Valid & & & \\
\hline \multirow[t]{3}{*}{$\mathrm{BC}$} & \multirow{3}{*}{$\begin{array}{l}\text { Business } \\
\text { Communitu }\end{array}$} & BC13 & 0,662 & Valid & BC31 & 0,760 & Valid \\
\hline & & $\mathrm{BC} 21$ & 0.820 & Valid & BC32 & 0,602 & Valid \\
\hline & & $\mathrm{BC} 22$ & 0,680 & Valid & & & \\
\hline \multirow{3}{*}{$\mathrm{CI}$} & \multirow{3}{*}{$\begin{array}{l}\text { Community } \\
\text { Involvement }\end{array}$} & CI22 & 0,604 & Valid & CI41 & 0,735 & Valid \\
\hline & & CI24 & 0,615 & Valid & C142 & 0,836 & Valid \\
\hline & & CI3 & 0,870 & Valid & & & \\
\hline \multirow[t]{4}{*}{ BIE } & \multirow{4}{*}{$\begin{array}{l}\text { Business } \\
\text { Islamic } \\
\text { Ethics }\end{array}$} & IBEI2 & 0,680 & Valid & IBE23 & 0,523 & Valid \\
\hline & & IBE13 & 0,827 & Valid & IBE31 & 0,807 & Valid \\
\hline & & IBE21 & 0,815 & Valid & IBE32 & 0,675 & Valid \\
\hline & & IBE22 & 0,739 & Valid & & & \\
\hline
\end{tabular}

Sumber: Hasil penelitian (2017) 
Tabel 4. Average Variance Extracted (AVE)

\begin{tabular}{|l|l|l|}
\hline Variabel & AVE & Kelayakan \\
\hline Profitability & 0,716 & $>0,50 \rightarrow$ layak \\
\hline Customer satisfaction & 0,585 & $>0,50 \rightarrow$ layak \\
\hline Employee engagement & 0,508 & $>0,50 \rightarrow$ layak \\
\hline Business community & 0,502 & $>0,50 \rightarrow$ layak \\
\hline Community involvement & 0,548 & $>0,50 \rightarrow$ layak \\
\hline Islamin business ethics & 0,534 & $>0,50 \rightarrow$ layak \\
\hline
\end{tabular}

Sumber: Diolah kembali dari hasil penelitian (2017)

Tabel 5. Cross Loading

\begin{tabular}{|c|c|c|c|c|c|c|}
\hline & $\begin{array}{l}\text { Business } \\
\text { community }\end{array}$ & $\begin{array}{l}\text { Community } \\
\text { involvement }\end{array}$ & $\begin{array}{l}\text { Customer } \\
\text { satisfaction }\end{array}$ & $\begin{array}{l}\text { Employee } \\
\text { engagement }\end{array}$ & $\begin{array}{l}\text { Islamic } \\
\text { business } \\
\text { ethic }\end{array}$ & Profitabilty \\
\hline BC13 & 0,662 & 0,322 & 0,380 & 0,384 & -0.057 & 0,186 \\
\hline BC21 & 0,820 & 0,380 & 0,351 & 0,283 & $-0,177$ & 0,141 \\
\hline BC22 & 0,680 & 0,454 & 0,281 & 0,357 & $-0,049$ & 0,292 \\
\hline BC31 & 0,760 & 0,427 & 0,060 & 0,174 & $-0,149$ & 0,187 \\
\hline BC32 & 0,602 & 0,366 & 0,115 & 0,342 & $-0,088$ & 0,070 \\
\hline CI12 & 0,382 & 0,604 & 0,232 & 0,380 & $-0,092$ & 0,069 \\
\hline CI24 & 0,296 & 0,615 & $-0,045$ & 0,197 & $-0,078$ & 0,109 \\
\hline CI3 & 0,475 & 0,870 & 0,150 & 0,304 & $-0,127$ & 0,105 \\
\hline CI41 & 0,471 & 0,735 & 0,116 & 0,441 & $-0,079$ & 0.074 \\
\hline CI42 & 0,402 & 0,836 & 0,075 & 0,252 & $-0,249$ & 0,153 \\
\hline CS11 & 0,215 & 0,157 & 0,714 & 0,219 & $-0,052$ & 0,189 \\
\hline CS12 & 0,278 & 0,141 & 0,794 & 0,259 & -0.058 & 0,144 \\
\hline CS14 & 0,217 & 0,084 & 0,671 & 0,238 & $-0,004$ & 0,120 \\
\hline CS2 & 0,246 & 0,085 & 0,854 & 0,276 & $-0,091$ & 0,197 \\
\hline CS32 & 0,220 & 0,044 & 0,777 & 0,205 & $-0,040$ & 0,113 \\
\hline EE11 & 0,302 & 0,311 & 0,098 & 0,631 & 0,126 & 0,030 \\
\hline EE12 & 0,225 & 0,226 & 0,222 & 0,524 & 0,021 & $-0,083$ \\
\hline EE21 & 0,314 & 0,306 & 0,316 & 0,838 & 0,177 & 0,020 \\
\hline EE23 & 0,291 & 0,348 & 0,121 & 0,793 & 0,198 & $-0,018$ \\
\hline EE24 & 0,253 & 0,211 & 0,307 & 0,737 & 0,097 & 0,113 \\
\hline EE3 & 0,332 & 0,301 & 0,215 & 0,762 & 0,097 & 0,179 \\
\hline EE4 & 0,192 & 0,200 & 0,379 & 0,653 & 0,120 & 0,044 \\
\hline IBE12 & $-0,127$ & $-0,258$ & $-0,118$ & 0,046 & 0,680 & $-0,349$ \\
\hline IBE13 & $-0,130$ & $-0,124$ & 0,006 & 0,196 & 0,827 & $-0,209$ \\
\hline IBE21 & $-0,106$ & $-0,111$ & $-0,097$ & 0,257 & 0,815 & $-0,244$ \\
\hline IBE22 & $-0,219$ & $-0,160$ & 0,056 & 0,059 & 0,739 & $-0,160$ \\
\hline IBE23 & $-0,088$ & $-0,066$ & 0,054 & 0,151 & 0,523 & $-0,015$ \\
\hline IBE31 & $-0,102$ & $-0,185$ & $-0,087$ & 0,189 & 0,807 & $-0,147$ \\
\hline IBE32 & $-0,130$ & -0.068 & $-0,155$ & 0,108 & 0,675 & $-0,130$ \\
\hline P12 & 0,115 & 0,114 & 0,171 & $-0,027$ & $-0,299$ & 0,958 \\
\hline P21 & 0,389 & 0.181 & 0,226 & 0,240 & $-0,123$ & 0,717 \\
\hline
\end{tabular}

Sumber: Hasil penelitian (2017) 
Tabel 6. Discriminant Validity dengan Fornell Larcker

\begin{tabular}{|c|c|c|c|c|c|c|}
\hline Indikator & $\begin{array}{l}\text { Business } \\
\text { community }\end{array}$ & $\begin{array}{l}\text { Community } \\
\text { involvement }\end{array}$ & $\begin{array}{l}\text { Customer } \\
\text { satisfaction }\end{array}$ & $\begin{array}{l}\text { Employee } \\
\text { engagement }\end{array}$ & $\begin{array}{l}\text { Islamic } \\
\text { business } \\
\text { ethics }\end{array}$ & Profitability \\
\hline $\begin{array}{l}\text { Business } \\
\text { community }\end{array}$ & 0,709 & & & & & \\
\hline $\begin{array}{l}\text { Community } \\
\text { involvement }\end{array}$ & 0,533 & 0,740 & & & & \\
\hline $\begin{array}{l}\text { Customer } \\
\text { satisfaction }\end{array}$ & 0,305 & 0,135 & 0,765 & & & \\
\hline $\begin{array}{l}\text { Employee } \\
\text { engagement }\end{array}$ & 0,380 & 0,388 & 0,312 & 0,713 & & \\
\hline $\begin{array}{l}\text { Islamic } \\
\text { business } \\
\text { ethics }\end{array}$ & $-0,175$ & $-0,206$ & $-0,082$ & 0,194 & 0,731 & \\
\hline Profitability & 0,219 & 0,150 & 0,211 & 0,058 & $-0,279$ & 0,846 \\
\hline
\end{tabular}

Sumber: Diolah kembali dari hasil penelitian (2017)

Tabel 7. Composite Reliability

\begin{tabular}{|l|l|l|}
\hline Variabel & $\begin{array}{l}\text { Composite } \\
\text { Reliability }\end{array}$ & Kelayakan \\
\hline Business community & 0,833 & $\geq 0,6 \rightarrow$ layak \\
\hline Community involvement & 0,856 & $\geq 0,6 \rightarrow$ layak \\
\hline Customer satisfaction & 0,875 & $\geq 0,6 \rightarrow$ layak \\
\hline Employee engagement & 0,876 & $\geq 0,6 \rightarrow$ layak \\
\hline Islamic business ethics & 0,887 & $\geq 0,6 \rightarrow$ layak \\
\hline Profitability & 0,832 & $\geq 0,6 \rightarrow$ layak \\
\hline
\end{tabular}

Sumber: Diolah kembali dari hasil penelitian (2017)

Tabel 8. Cronbach's Alpha

\begin{tabular}{|l|l|l|}
\hline Variabel & $\begin{array}{l}\text { Cronbach's } \\
\text { alpha }\end{array}$ & Kelayakan \\
\hline Business community & 0,766 & $\geq 0,6 \rightarrow$ layak \\
\hline Community involvement & 0,820 & $\geq 0,6 \rightarrow$ layak \\
\hline Customer satisfaction & 0,845 & $\geq 0,6 \rightarrow$ layak \\
\hline Employee engagement & 0,844 & $\geq 0,6 \rightarrow$ layak \\
\hline Islamic business ethics & 0,857 & $\geq 0,6 \rightarrow$ layak \\
\hline Profitability & 0,655 & $\geq 0,6 \rightarrow$ layak \\
\hline
\end{tabular}

Sumber: Diolah kembali dari hasil penelitian (2017)

Tabel 9. R-Square Adjusted

\begin{tabular}{|l|l|l|l|l|l|}
\hline Model & $\begin{array}{l}\text { Variabel } \\
\text { Independen }\end{array}$ & $\begin{array}{l}\text { Variabel } \\
\text { Dependen }\end{array}$ & $\mathbf{R}^{2}$ & T Statistik & $\begin{array}{l}\text { Nilai } \mathbf{p}(\boldsymbol{V} \text { - } \\
\text { value) }\end{array}$ \\
\hline Model 1 & & $\begin{array}{l}\text { Business } \\
\text { community }\end{array}$ & 0,031 & & \\
\hline
\end{tabular}




\begin{tabular}{|c|c|c|c|c|c|}
\hline & \multirow{5}{*}{$\begin{array}{l}\text { Islamic } \\
\text { business } \\
\text { ethics }\end{array}$} & & $(3,1 \%)$ & 1,241 & 0,215 \\
\hline Model 2 & & $\begin{array}{l}\text { Community } \\
\text { involvement }\end{array}$ & $\begin{array}{l}0,042 \\
(4,2 \%)\end{array}$ & 1,686 & 0,092 \\
\hline Model 3 & & $\begin{array}{l}\text { Customer } \\
\text { satisfaction }\end{array}$ & $\begin{array}{l}0,007 \\
(0,7 \%)\end{array}$ & 0,460 & 0,645 \\
\hline Model 4 & & $\begin{array}{l}\text { Employee } \\
\text { engagement }\end{array}$ & $\begin{array}{l}0,038 \\
(3,8 \%)\end{array}$ & 1,313 & 0,190 \\
\hline Model 5 & & Profitability & $\begin{array}{l}0,078 \\
(7,8 \%)\end{array}$ & 2,808 & 0.005 \\
\hline
\end{tabular}

Sumber: Diolah berdasarkan hasil penelitian (2017)

Tabel 10. Uji Hipotesis

\begin{tabular}{|c|c|c|c|c|c|c|}
\hline Hipotesis & $\begin{array}{l}\text { Variabel } \\
\text { Independen }\end{array}$ & $\begin{array}{l}\text { Variabel } \\
\text { Dependen }\end{array}$ & $\begin{array}{l}\text { Koefisien } \\
\text { Deter- } \\
\text { minasi }(\beta)\end{array}$ & $\begin{array}{l}T \\
\text { Statis- } \\
\text { tics }\end{array}$ & $\begin{array}{l}\text { P- } \\
\text { Value }\end{array}$ & Signifi-kansi \\
\hline $\mathrm{H}_{1}$ & \multirow{5}{*}{$\begin{array}{l}\text { Islamic } \\
\text { business } \\
\text { ethics }\end{array}$} & $\begin{array}{l}\text { Business } \\
\text { community }\end{array}$ & $\begin{array}{l}0,031 \\
(3,1 \%)\end{array}$ & 1,241 & 0,215 & $\begin{array}{l}\text { Tidak } \\
\text { signifikan }\end{array}$ \\
\hline $\mathrm{H}_{2}$ & & $\begin{array}{l}\text { Community } \\
\text { involvement }\end{array}$ & $\begin{array}{l}0,042 \\
(4,2 \%)\end{array}$ & 1,686 & 0,092 & $\begin{array}{l}\text { Tidak } \\
\text { signifikan }\end{array}$ \\
\hline $\mathrm{H} 3$ & & $\begin{array}{l}\text { Customer } \\
\text { satisfaction }\end{array}$ & $\begin{array}{l}0,007 \\
(0,7 \%)\end{array}$ & 0,460 & 0,645 & $\begin{array}{l}\text { Tidak } \\
\text { signifikan }\end{array}$ \\
\hline $\mathrm{H} 4$ & & $\begin{array}{l}\text { Employee } \\
\text { engagement }\end{array}$ & $\begin{array}{l}0,038 \\
(3,8 \%)\end{array}$ & 1,313 & 0,190 & $\begin{array}{l}\text { Tidak } \\
\text { signifikan }\end{array}$ \\
\hline H5 & & Profitability & $\begin{array}{l}0,078 \\
(7,8 \%)\end{array}$ & 2,808 & 0.005 & Signifikan \\
\hline
\end{tabular}

Sumber: Diolah berdasarkan hasil penelitian (2017)

Tabel 11. Perhitungan $Q^{2}$ Predictive Relevance

\begin{tabular}{|c|c|c|c|c|}
\hline Model & $\begin{array}{l}\text { Variabel } \\
\text { Inde- } \\
\text { penden }\end{array}$ & $\begin{array}{l}\text { Variabel } \\
\text { Dependen }\end{array}$ & $\mathbf{R}^{2}$ & Perhitungan $Q^{2}$ Predictive Relevance \\
\hline Model 1 & \multirow{3}{*}{$\begin{array}{l}\text { Islamic } \\
\text { business } \\
\text { ethics }\end{array}$} & $\begin{array}{l}\text { Business } \\
\text { community }\end{array}$ & 0,031 & $\begin{array}{l}\mathrm{Q}^{2}=1-\left(1-\mathrm{R}_{1}{ }^{2}\right)=1-\left(1-0,031^{2}\right)=1-(1-0.001) \\
=1-0.999=0.001\end{array}$ \\
\hline Model 2 & & $\begin{array}{l}\text { Communi- } \\
\text { ty involve- } \\
\text { ment }\end{array}$ & 0,042 & $\begin{array}{l}\mathrm{Q}^{2}=1-\left(1-\mathrm{R}_{1}^{2}\right)=1-\left(1-0,042^{2}\right)=1-(1-0,002)= \\
1-0,998=0,998556\end{array}$ \\
\hline Model 3 & & $\begin{array}{l}\text { Customer } \\
\text { satisfac- } \\
\text { tion }\end{array}$ & 0,007 & $\mathrm{Q}^{2}=1-\left(1-\mathrm{R}_{1}^{2}\right)=1-\left(1-0,007^{2}\right)=1-(1-$ \\
\hline
\end{tabular}




\begin{tabular}{|c|c|c|c|}
\hline & & & $0,00049)=1-0,99951=0,00049$ \\
\hline Model 4 & $\begin{array}{l}\text { Employee } \\
\text { enga- } \\
\text { gement }\end{array}$ & 0,038 & $\begin{array}{l}\mathrm{Q}^{2}=1-\quad\left(1-\mathrm{R}_{1}^{2}\right)=1-\left(1-0,038^{2}\right)=1-(1- \\
0,001444)=1-0,998556=0,001444\end{array}$ \\
\hline Model 5 & $\begin{array}{l}\text { Profita- } \\
\text { bility }\end{array}$ & 0,078 & $\begin{array}{l}\mathrm{Q}^{2}=1-\left(1-\mathrm{R}_{1}^{2}\right)=1-\left(1-0,078^{2}\right)=1-(1- \\
0,006084)=0,993916\end{array}$ \\
\hline
\end{tabular}

Sumber: Diolah berdasarkan hasil penelitian (2017)

\section{Kesimpulan:}

1. Artikel ini tidak didukung oleh kajian literatur yang kuat.

2. Model yang dibangun tidak berdasarkan penelitian pendahuluan.

2. Pembahasan tidak tajam dan mendalam, salah satu disebabkan oleh kurangnya kajian literatur yang digunakan terkait dengan variabel yang digunakan dalam penelitian ini.

3. Kesimpulan tidak berdasarkan hasil pengolahan data.....

\section{Saran;}

Artikel ini tidak layak untuk di publish....

Kalau memungkinkan untuk di publish, lakukan perbaikan mendasar sesuai dengan komentar reviewer:

Tambahkan kajian literatur yang mengungkapkan hubungan antar variabel yang diteliti.

Perbaiki model serta lakukan pengolahan ulang.

\section{Saran Model Penelitian}

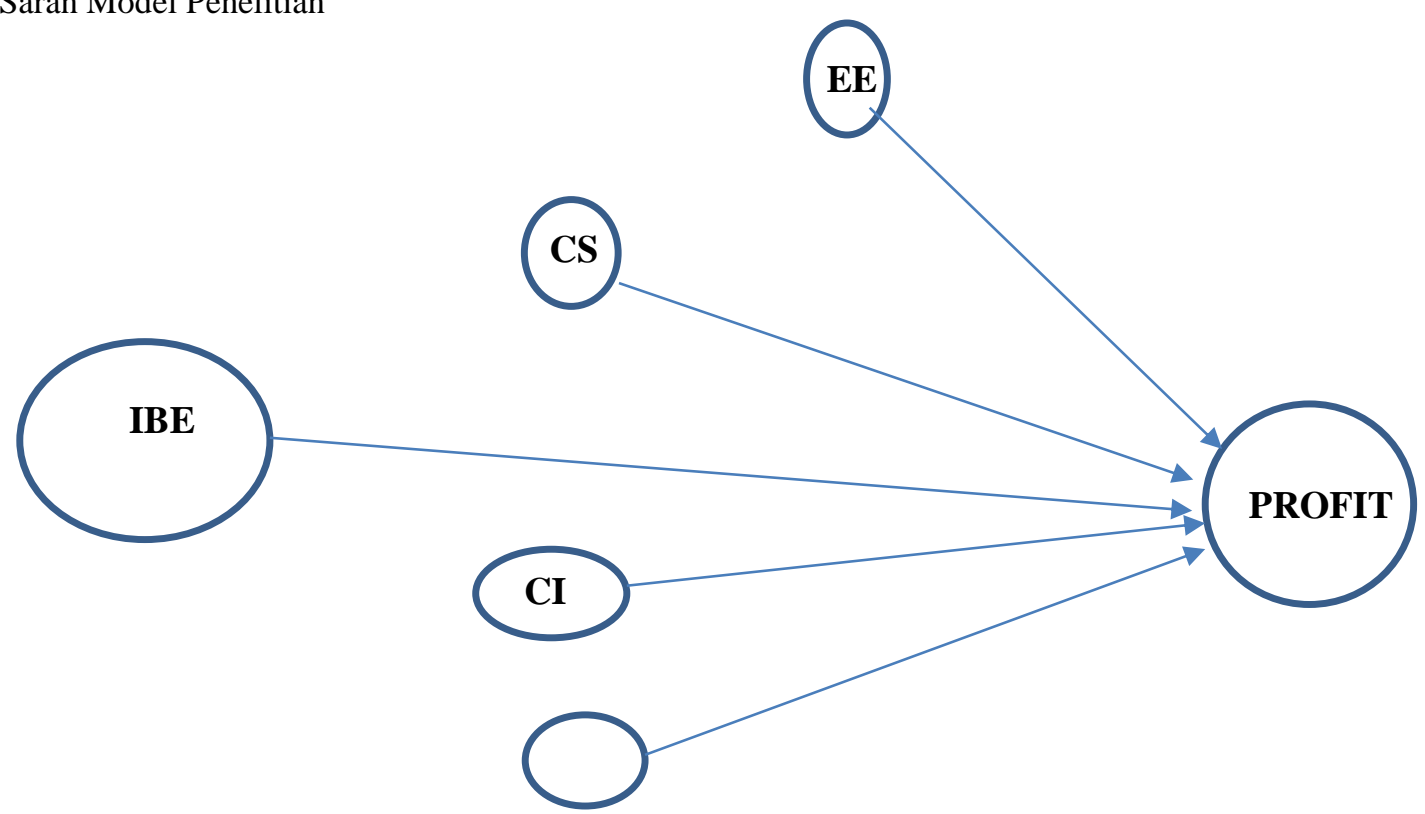

